\title{
Professional attributes of young specialists: expectations of municipal employees in rural areas
}

\author{
Ambartsum Galustov ${ }^{1}$, Yuri Lobeyko ${ }^{2}$, Svetlana Levushkina ${ }^{3}$, Olga Mandritsa ${ }^{4}$, and \\ Valentine Ivashova ${ }^{3, *}$ \\ ${ }^{1}$ Armavir State Pedagogical University, 159, R. Luxenburg st., Armavir, 352901, Russia \\ ${ }^{2}$ North Caucasus Federal University, 1, Pushkin Str., Stavropol, 355017, Russia \\ ${ }^{3}$ Stavropol State Agrarian University, 12, Zootechnicheskiy lane, Stavropol, 355017, Russia \\ ${ }^{4}$ MIREA - Russian Technological University, Branch in Stavropol, 8, Kulakova ave., Stavropol, \\ 355000, Russia
}

\begin{abstract}
The article presents the results of a survey of municipal employees in rural areas of the Stavropol Territory. The purpose of the study was to determine the important professional attributes (characteristics) of young professionals who come to the ranks of the municipal service in rural areas of the region. In total, 247 municipal employees from 10 municipal districts of the Stavropol Territory took part in the expert survey. Comparisons of the views of young specialists and specialists with more than 10 years of work experience in the municipal service show significant differences in the set of important professional attributes formed during the period of study at the university. The characteristics are the starting point during the period of professional socialization directly to the position of a municipal employee. According to municipal employees with up to 5 years of service, the key professional attributes should be willingness to reproduce professional status-role relationships; readiness to perform a professional function - the development and adoption of management decisions; willingness and participation in innovation in the workplace. According to municipal employees with over 10 years of experience, the key professional attributes are the willingness to adequately respond to the requirements of the professional environment; informational and functional readiness for professional development.
\end{abstract}

\section{Introduction}

Modern global trends in optimization of territorial management, first of all, speak of the validity of the trend for sustainable development, both of individual organizations, municipalities and regions. In this regard, an important role is played by managerial staff; they are called upon to implement the set tasks of sustainability in specific decisions and actions $[1,2]$. Managerial staff of rural municipalities is included in these processes due to

* Corresponding author: vivashov@mail.ru 
the need to preserve and develop agricultural regions, to ensure food and territorial security of the country. The study of the necessary list of professional attributes (characteristics) of young specialists who come to the ranks of the municipal service of rural areas of the region is a relevant and important area of socio-economic research, both in Russia and abroad.

Municipal service managers must have not only a stock of knowledge and skills in their application, but also leadership activity to promote ideas of sustainability and preservation of rural areas. The author Corriveau A., in her article, offers proven educational practices of a Canadian university [3]. Analyzing the approaches to the implementation of the sustainable development goal adopted in 2015 by the UN, the author makes an important judgment that it is the leaders who should become agents of change to achieve this goal. Their professional training should at its core have a clear set of socially significant ethical values that determine the actions of leaders. In our opinion, this statement is also very relevant for municipal employees of rural areas, who in their professional practices are faced with complex socio-economic issues: environmental management, a lower standard of living in comparison with the city, the availability of high-quality services in education, medicine, culture, social and psychological stress and dissatisfaction of the rural population with life. To overcome these situations, leaders are needed with certain personal qualities and a high level of labor motivation [4] and capable of involving the local community in positive transformations [5, 6, 7]. The authors of Gyensare M. A., Kumedzro L. E., Sanda, A., Boso N. also speak about the relevance of this approach in their article [8].

The issues of sustainable development of territories and the associated professional attributes of managers that can organize their achievement are discussed by the authors of the article Muffa K., Kapalkaa A., Dyllickb Th. [9]. They emphasize the need to develop tools for the correct decomposition of goals at the national level. This is relevant at the regional level and provides an opportunity to measure progress in achieving the sustainable development goals. An important aspect, sounded in the conclusions, is the need for the unity of indicators and understanding of the dynamics of socio-economic processes of territories, which makes it possible to compare and introduce the best experience. Accordingly, municipal officials should have the full knowledge and skills of planning, monitoring achievements and benchmarking comparisons aimed at ensuring sustainable development of territories.

The economic component of sustainable development of rural areas plays an important role in connection with the need to overcome the problems of seasonal employment in the agricultural sector, a lower standard of living of the population and, ultimately, depopulation of the village. Municipal managers must have the full entrepreneurial qualities that can ensure the economic prosperity of localities. The study of the authors Mozahema N., Adlounib R. is devoted to the development and testing of a system of criteria for assessing entrepreneurial efficiency. Achievement of entrepreneurial self-efficacy, in their opinion, is noted among employees with the following attributes: creative approach in setting tasks; information search skills; planning under conditions of uncertainty; adaptability; financial management; teamwork; critical thinking; communication skills; self-government [10]. In the list of characteristics of entrepreneurial efficiency, the authors proposed systemic indicators for each named attribute. For a comprehensive understanding of the attributes of young specialists in the municipal service of rural areas, such a systematic approach is important. A more extended interpretation of such an indicator as teamwork is presented in the work of the authors Thomas A., O'Neilla E. S. [11]. The relevance of the study of approaches to the organization of effective production teams is dictated by the increasingly complex conditions of modern work and the need to realize the potential of working groups. For rural areas with limited access to human resources, the issue of effective use of the command potential of working groups becomes highly relevant 
due to the scale of management tasks, activities in conditions of limited resources, multitasking and a high level of uncertainty. In educational programs of managers, it is necessary to pay special attention to the formation of readiness to work in a changing production environment $[12,13]$ and continuous professional development $[14,15]$.

Authors Martynova S. E., Maslennikova O. G. in their publication note the need to create a complex attributive model of a municipal and civil servant and timely update it based on the expectations of leaders and specialists at the municipal and regional level [16].

Thus, the review of publications confirms the relevance of the study of professional attributes (characteristics) of young specialists from the point of view of the expectations of municipal employees in rural areas.

\section{Materials and methods}

A number of municipal districts were officially transformed into urban districts with the corresponding abolition of settlements after changes in the territorial division from June 1, 2017 in the Stavropol Territory. The number of municipalities is: 17 urban districts, 16 municipal districts, which include 2 urban settlements, 166 rural settlements.

A sociological study of the professional attributes of municipal employees in rural settlements was conducted in December 2019 using the method of an expert survey. Geographically, 30 survey points were identified, representing 10 municipal districts of the Stavropol Territory with distribution by zones -North-Western part (zone I); Central part (zone II); Caucasian Mineral Waters Region (zone III); Southern part (zone IV); Eastern part (zone V).

An electronic questionnaire was sent to potential respondents - municipal employees of the district and rural administrations of the Stavropol Territory. In total, 300 questionnaires were sent out, 247 people actually took part in the expert survey. The return was $82.3 \%$, almost two thirds. The high return of the questionnaires was insured by a motivation letter and subsequent informing the management of potential respondents through phone calls about the importance of the study for improving the quality of municipal governance.

In the process of answering the questionnaire, the experts assessed the universal professional attributes of young specialists currently working as municipal employees in the Stavropol Territory. The following table provides comparative data.

Table 1. Distribution of answers to the question: Evaluate, on a five-point scale, to what extent graduates of higher education in recent years have the following qualities.

\begin{tabular}{|l|c|c|c|}
\hline \multirow{2}{*}{ Answer options } & \multicolumn{2}{|c|}{$\begin{array}{c}\text { How much they possess } \\
\text { the specified quality }\end{array}$} & \multirow{2}{*}{ Total } \\
\cline { 2 - 3 } & $\begin{array}{c}\text { Young } \\
\text { professionals }\end{array}$ & $\begin{array}{c}\text { Experienced } \\
\text { professionals }\end{array}$ & \\
\hline 1. Ability to set professional tasks & 3.5 & 3.7 & 3.6 \\
\hline 2. Ability to highlight probable problems at work & 3.3 & 3.7 & 3.5 \\
\hline $\begin{array}{l}\text { 3. Ability to develop solutions and evaluate their } \\
\text { effectiveness }\end{array}$ & 3.2 & 3.7 & 3.5 \\
\hline 4. Ability to use modern technical equipment & 4.3 & 4.1 & 4.2 \\
\hline $\begin{array}{l}\text { 5. Ability to independently extract and interpret the } \\
\text { necessary information }\end{array}$ & 4.4 & 4.3 & \multirow{2}{*}{4.4} \\
\hline 6. Ability to plan your career & 3.2 & 3.8 & 3.5 \\
\hline 7. Organize yourself and others & 3.4 & 3.6 & 3.5 \\
\hline 8. Positive attitude towards change & 3.8 & 4.1 & 4.0 \\
\hline 9. Ability to take criticism positively & 3.1 & 3.8 & 3.5 \\
\hline
\end{tabular}


In order to get an idea of the difference in the assessments of young specialists and specialists with more than 10 years of experience, a factor analysis was carried out for the selected categories of experts.

The respondents' assessments were put on a 5-point scale from low quality significance (1 point) to high quality significance (5 points). In the database of the questionnaire survey using the SPSS software (version 21), factor analysis was carried out - with the help of which, a large number of variables were reduced to fewer independent influencing factors. In this case, several variables, strongly correlated with each other, are brought together into a certain factor, for a more complete explanation of the observed relationships between the variables.

The task of factor analysis is to carry out a comparison study of the understanding of significant professional attributes by municipal employees with a short work experience less than 5 years and those with more than 10 years of experience in municipal service.

The full explained variance for the "young professionals" category is $89.6 \%$ and is determined by 3 components.

Using rotation method varimax with Kaiser normalization, the matrix rotations were carried out for respondents in the category of "young professionals" and, as a result, a matrix of rotated components was obtained. Rotation converged in 6 iterations.

\section{Results and discussion}

An analysis of the matrix of rotated components for respondents in the category of "young professionals" shows that the third variable, the ability to develop solutions and evaluate their effectiveness (coefficient 0.646), received the greatest workloads for the first factor, the sixth variable, the ability to positively perceive criticism (coefficient $\mathbf{0 . 9 6 5}$ ), and the seventh, the ability to plan their career (coefficient $\mathbf{0 . 8 1 7}$ ) and the ninth variable - the ability to organize themselves and others (coefficient $\mathbf{0 . 8 4 0}$ ). Moreover, in quantitative terms, the relevance of the variable prevails - the ability to positively perceive criticism with a weight coefficient of $\mathbf{0 . 9 6 5}$. Thus, the first factor can be interpreted according to the cumulative perception of the included variables as "readiness for the reproduction of professional status-role relations".

The second factor for the category of "young professionals" consists of variables: the first is the ability to set professional goals and objectives (coefficient $\mathbf{0 . 8 6 9}$ ), the second is the ability to identify probable problems in work (coefficient $\mathbf{0 . 9 2 1}$ ), the fifth is the ability to independently obtain and interpret the necessary information (coefficient $\mathbf{0 . 8 2 2}$ ). The second variable with the highest coefficient in this group is the ability to identify probable problems at work $\mathbf{0 . 9 2 1}$. The second factor can be meaningfully interpreted as "readiness to perform a professional function - the development and adoption of managerial decisions".

The third factor for the "young specialists" category consists of variables: the fourth is the ability to use modern technical equipment (coefficient $\mathbf{0 . 9 9 0}$ ), the eighth is a positive attitude towards changes (coefficient $\mathbf{0 . 6 0 3}$ ). Analysis of the semantic content of the variables that are part of this factor allows us to call it in general terms - "readiness and participation in innovations in the current labor process". This attributive characteristic plays an important role in the period of digitalization and the transition to electronic document management at all levels of government in the Russian Federation, including at the level of municipal government.

The full explained variance for observations from the database of respondents who belong to the category of experienced specialists is $77.9 \%$ and is determined by 2 components. 
Based on the analysis of the main components, a matrix of components was identified for respondents in the category of "specialists with more than 10 years of experience", which includes 2 components. Using the rotation method varimax with Kaiser normalization, the matrix rotations were carried out for the respondents of the category "specialists with more than 10 years of experience" and, as a result, we obtained a matrix of rotated components. The rotation converged in 3 iterations.

Analysis of the matrix of rotated components for respondents in the category of "specialists with more than 10 years of experience" shows that the greatest workloads for the first factor are received by: the first variable - the ability to set professional goals and objectives (coefficient $\mathbf{0 . 7 8 8}$ ); the second variable is the ability to identify probable problems at work (coefficient $\mathbf{0 . 8 7 8}$ ); the third variable is the ability to develop solutions and evaluate their effectiveness (coefficient $\mathbf{0 . 9 4 7}$ ); the fourth variable is the ability to use modern technical equipment (coefficient $\mathbf{0 . 8 2 8}$ ); the seventh variable is the ability to plan your career (coefficient $\mathbf{0 . 6 8 4}$ ). Moreover, in quantitative terms, the relevance of the variable prevails - the ability to develop solutions and evaluate their effectiveness $\mathbf{0 . 9 4 7}$. Thus, the first factor can be interpreted in terms of the aggregate perception of the included variables as "the readiness to adequately respond to the demands of the professional environment".

The second factor for the category "specialists with more than 10 years of experience" consists of the following variables: the fifth - the ability to independently extract and interpret the necessary information (coefficient $\mathbf{0 . 5 4 9}$ ); the sixth - the ability to perceive criticism positively (coefficient $\mathbf{0 . 7 8 6}$ ); the eighth - a positive attitude to changes (coefficient $\mathbf{0 . 8 3 8}$ ); the ninth - the ability to organize oneself and others (coefficient $\mathbf{0 . 8 2 2}$ ). With the highest coefficient in this group, the eighth variable is a positive attitude to changes of $\mathbf{0 . 8 3 8}$. The second factor can be meaningfully interpreted as "informational and functional readiness for professional development".

To update the competencies in the educational program of bachelors of the educational program "State and Municipal Administration", profile "Municipal Administration", provided for by the Federal State Educational Standard 3+, experts in the framework of the survey conducted their ranking.

The results of ranking by the expert professional community of competencies according to the degree of importance show that among the key ones are highlighted:

1 st place - the ability to use the foundations of economic knowledge in various fields of activity; the ability to work in a team, tolerantly perceiving social, ethnic, confessional and cultural differences; possession of the skills of searching, analyzing and using normative and legal documents in their professional activities (noted respectively by $71.4 \%$ of survey participants);

2nd place - the ability to use the basics of legal knowledge in various fields of activity (noted by $57.1 \%$ of survey participants);

3rd place - the ability to analyze the main stages and patterns of the historical development of society for the formation of a civic position; the ability for self-organization and self-education; the ability to solve standard tasks of professional activity based on information and bibliographic culture using information and communication technologies and taking into account the basic requirements of information security; possession of the skills of quantitative and qualitative analysis in assessing the state of the economic, social, political environment, the activities of the state authorities of the Russian Federation, state authorities of the constituent entities of the Russian Federation, local authorities, state and municipal, enterprises and institutions, political parties, socio-political, commercial and non-profit organizations; possession of technologies, techniques, ensuring the provision of state and municipal services to individuals and legal entities; the ability to plan and ensure 
the operational management of the organization's human resources at the municipal level (each of the listed competencies was noted by $28.6 \%$ of the survey participants).

The expert community assessed the competencies from the Federal State Educational Standard according to the degree of formation among graduates of the educational program 38.03.04 "State and Municipal Administration", profile "Municipal Administration", which shows that competence remains less formed - the possession of methods and specialized tools for analytical work and scientific research (noted by $28.6 \%$ of the respondents).

\section{Conclusion}

The Thus, the conducted comparisons of the views of young specialists and specialists with more than 10 years of work experience in the municipal service show significant differences in the set of important professional attributes formed during the period of study at the university. They are the starting point during the period of professional socialization directly to the position of a municipal employee.

Factors of the category "young professionals":

- the first factor is "readiness for the reproduction of professional status-role relations";

- the second factor is "readiness to perform a professional function - the development and adoption of management decisions";

- the third factor is "willingness and participation in innovations in the current labor process".

Factors of the category "experienced specialists":

- the first factor is "readiness to adequately respond to the requirements of the professional environment";

- the second factor is "informational and functional readiness for professional development".

According to the municipal employees of the rural areas of the Stavropol Territory, who took part in the expert survey, it is important for young specialists to be able to use the basics of economic knowledge in various fields of activity; work in a team, tolerantly perceiving social, ethnic, confessional and cultural differences; possession of the skills of searching, analyzing and using normative and legal documents in their professional activities (noted respectively by $71.4 \%$ of survey participants); use the basics of legal knowledge in various fields of activity (noted by $57.1 \%$ of survey participants).

All of the above attributes of young specialists of the municipal service of rural areas are the basis for improving the educational programs of the bachelor's degree and enhance the readiness of graduates for a successful labour process.

\section{References}

1. V. Ivashova, G. Tokareva, E. Agalarova, Y. Nadtochiy IOP Conference Series: Materials Science and Engineering, 775(1) 012020 (2020)

2. V. Goncharov, A. Erokhin, O. Kolosova,V. Ivashova IOP Conference Series: Earth and Environmental Science, 422(1) 012127 (2020)

3. A. Corriveau The International Journal of Management Education, 18(1) 100364 (2020)

4. T. S. Mhlanga, T. Q. Mjoli, S.F. Chamisa $S$ A Journal of Human Resource Management, 17 Available at: https://doi.org/10.4102/sajhrm.v17i0.1188 (2019)

5. Y. Liao, L. Ma Public Management Review, 21(12) 1824-1847 (2019) https://doi.org/10.1080/14719037.2019.1577907 
6. Y. Zhang, K. Yang Journal of Public Budgeting, Accounting \& Financial Management, 21(2) 289-317 (2009) Available at: https://doi.org/10.1108/jpbafm-2102-2009-b006

7. J. Beckett, C.S. King Journal of Public Budgeting, Accounting \& Financial Management, 14(3) 463-485 (2002) https://doi.org/10.1108/jpbafm-14-03-2002-b007

8. M.A. Gyensare, L.E. Kumedzro African Journal of Economic and Management Studies, 8(3) 314-337 (2017) https://doi.org/10.1108/AJEMS-07-2016-0099

9. K. Muffa, A. Kapalkaa The International Journal of Management Education, 15(2) 363-383 (2017)

10. N. Mozahema, R. Adlounib The International Journal of Management Education, 18(1) 100385 (2020)

11. A. Thomas, E. S. O'Neilla Human Resource Management Review, 28(4) 325-331 11 (2018)

12. I. Herberta, A. Rothwella, J. Gloverb, S. Lamberta The International Journal of Management Education, 18(2) 100378 (2020)

13. G. Kennett Australian Bulletin of Labour, 39(1) 112-135 (2013)

14. R. Mahmood, O. C. Hee, O. S. Yin Hamli M S H 2018 International Journal of Academic Research in Business and Social Sciences, 8(7) https://doi.org/10.6007/ijarbss/v8-i7/4410

15. N. S. Al-Mannaee International Journal of Work Organisation and Emotion, 9, 107124 (2018) https://doi.org/10.1504/IJWOE.2018.10012448

16. S. E. Martynova, O. G. Maslennikova Procedia - Social and Behavioral Sciences, 174 2716-2720 (2015) https://doi.org/10.1016/j.sbspro.2015.01.957 